\title{
ISG15 Gene
}

National Cancer Institute

\section{Source}

National Cancer Institute. ISG15 Gene. NCI Thesaurus. Code C104657.

This gene is involved in both protein tagging and cell signaling. 